\title{
Utopian Thinking and Contemporary Reality
}

\author{
Olga Khalutornykh \\ Bauman Moscow State Technical University \\ 5/1, 2nd Baumanskaya Street \\ Moscow, Russia 105005 \\ E-mail: olganik@yandex.ry \\ Lomonosov Moscow State University \\ 27/4 Lomonosovsky Ave \\ Moscow, Russia 119992 \\ E-mail: olganik@yandex.ru
}

\begin{abstract}
The image of a society, arbitrarily designed by mass consciousness, acting as an object of human practical activity, giving samples of social life invariably reflect utopias. Utopianism in all historical versions, considers society as a mechanical system, suggesting that it is possible to establish a perfect social order by organizational methods. Ethical norms of utopia appear as a system of regulatory imperatives that express the interests of certain social groups and the social reference point of a person in society. But the utopian social ideal of mass consciousness represents a value model of the average person for whom the higher spiritual values are substituted for profit, the desire for truth is well-being, happiness is bought at the cost of freedom, individuality is treated as a rebellion against public order.
\end{abstract}

Keywords-are utopia; utopian thinking; dystopia; mass consciousness; utopian expectations; social ideal; state structure; utopian society

\section{INTRODUCTION}

... Utopia turned out to be much more feasible than before.

And now there is another painful question, how to avoid their final implementation ...

N. Berdyaev

The critical understanding of the existing order of things, the rejection of social order, invariably engenders a desire to change reality, create an ideal new world shining with happiness, a world of utopia more consistent with the notion of harmonious, just society. Utopia is a part of religious beliefs, ethical and legal theories, systems of education, poetic works that give examples of human life. It is impossible to imagine no one single epoch, no one nation, no one man who would not have a dream about paradise on the earth, and therefore would not have been more or less an utopian. Wherever there is poverty, injustice, suffering, lawlessness, an utopian projects arises, for searching meanings that can destroy the cause of evil. "Throughout the history of culture there passes a whole ladder of most various types of utopia - from the ideas of a wild nomad to the reflections of a modern philosopher ..." [1]. The utopian model, evaluating empirical reality, becomes a way of both understanding and criticizing the life world that does not correspond to social values, becomes either an object of contemplation or a task of practical activity, being one of ideological constructs, appointed to control the mass consciousness.

\section{UTOPIA AS A WAY OF THINKING}

From ancient times to the present day, the great minds of mankind (Plato, Iamblichus, T. Moore, T. Campanella, F. Bacon and many others) sought the island of happiness, mentally traveling to a country that does not exist. Each epoch created its own ideal of the state structure, that depends on the author's world view, as well as the social organization of society where he lived. Traditionally, the main types of utopian structures considered as: "compensatory project" - the idealization of the past, the legend of the golden age of mankind, the model of a perfect world, as alternative to the existing society.

It should be noted that Utopia is functionally different from stories about the future, which no descripted the system of state structure; novels, describing underground, underwater worlds, similar to terrestrial; literary texts about imaginary wars; science fiction novels, focusing on the technology of the future, and not on its social structure (despite the fact that science fiction is often considered part of utopian literature).

Specificity of utopia is determined by the way of producing a social ideal, Appearance of rationalistic projects of ideal state in the $\mathrm{V}$ century $\mathrm{BC}$ meant the transition of human thought to a qualitatively new stage expressed in the first attempt at a theoretical comprehension of the nature of socio-political processes, the desire to overcome the negative consequences of the development of civilization, relying not on the power of supernatural forces, but on the human mind. Destruction of the habitat, the weakening of traditional values, norms, the disintegration of previous social ties led to the idealization of the "lost" world, the past. The philosophers of Greece and Rome (Plato, Aristotle, Zeno, Yambul, Evgemer) mourned for the "golden age", the lost 
innocent life - without envy, jealousy, enmity. They dreamed of a harmonious world that is different from reality, chaos, elements under the control of the highest and absolute law, creating projects of the perfect state - the archetype of utopia for all times, where the inseparability of the individual principle is manifested and realized through the "fusion" of personal meaning and social values. The development of social relations generates other social ideals. In the utopias of the Renaissance (T. Mor, T. Campanella), New Times (F. Bacon, Cyrano de Bergerac, Denis Veras), ethical norms of a new historical era are consolidated and propagated. The utopian plot presents moral situations through which the individual experiences the universality of moral imperatives, often backed up by religious arguments. Thus, the rationalethical essence (abstract commonality) of autonomous individuals is affirmed as a social value and personal meaning. Value norms function as directly experienced ways of socialization of individuals, ensuring the stability of society.

Utopia, becoming a synonym for the moral, social ideal, becomes an integral picture of the relations that its creator considers absolute, comprehensively designing the social organization, in detail, creating an ideal system, the balance between the constituent parts of which must be preserved. The model designed by the intellectual mind is functioning as a standard, a measure of the existing reality. The more significant the life corresponds to the utopian ideal, the more valuable it is for the author-theoretician. The French critic Georges Sorel calls utopias ideal systems that arose as a result of intellectual speculation, divorced from "living" reality and real experience [2]. In such a situation, social theoretical thought easily passes from casualness to teleologism. The goal, as a result of the scientific forecast, and the utopian ideal appear in unity.

Because of this, utopia-confirmed values are the principle of organizing the available social life, an effective means of socializing the individual. They are concentrated desires, aspirations, expectations of a social group, its emerging ideas about the proper future become a criterion for assessing the existing being. In this context, the ethical norms of utopia appear as a system of regulatory ethical norms of utopia appear as a system of regulatory ideas, imperatives that express the interests of certain social groups and are a guide of man in society. There is a kind of "secular sacralization" of the principles of power and subordination, dependence and freedom, inequality and justice. A certain historically concrete form of sociality becomes an absolute norm, orienting a person to proper behavior in a "true" real world where ethical norms appear as an unproblematized given.

The danger of utopian thinking lies in the fact that utopia does not have the authority of scientific proof (what the narrator saw in his journey may turn out to be a lie, fiction, etc.) and, therefore, easily penetrates the rational-critical barriers. The scientific forecast, based on the authority of truth, must prove its negative and positive assessments. Theoretical rational thinking, striving for universality and objectivity, departs from the author's subjective assessment natural for art. Utopia as an artistic and scientific genre makes up for the lack of expressive means of rational thinking. Public relations "domination-subordination", functioning according to the canons of artistic reality, receive a logical-aesthetic argumentation and evidence. In this context, the aestheticization of violence provides ethical legitimacy. Thus, the artistic reality of utopia from an aesthetic phenomenon turns into an ideological phenomenon.

The artistic reality of utopia is a kind of laboratory in which mental experiments are put, models of the social connection of individuals, value norms (measures), fixing the limited (subject-object) relationship of a person to the world and to himself, are being established, in which "escape from freedom "Appears an illusory justification for the alienation of individuals and an illusory way to overcome it. A person is regarded as a creature, expediently transforming its existing world of being, which believes and creates its essence in this process. In specific individual actions, he realizes his own rationally known nature, which is a prerequisite for a virtuous, and therefore happy life. Values in this case function in society as reasonably justified norms of socialization of the individual, the ideal model of the "proper" person.

The idea of weal, universal prosperity acquires the status of a life project, imperatively demanding its practical embodiment, implementation. The desire of mankind to live up to the time when "stones turn into bread" is so great that it successfully supersedes thoughts about the freedom and uniqueness of each, eternal values that make up the moral image of a person, giving a higher meaning to his stay on earth among temptations. A vivid example of this is the classical utopias of T. Mora, T. Cambanella, F. Bacon, E. Bellamy, where reason subdues nature, and reliance on powerful technology and technology to suppress the traditional "human" aspects of life are based on the principles of mass consciousness management.

Such mechanisms often in practice serve the implementation of inquisitorial purposes: to teach to whom to bow, to whom to hand the conscience, how to unify community into an overall "agree" anthill. In a world like that, the concept of freedom is equated with the concept of sin, the right to be free - to the right to be unhappy. In a rationalized utopian reality, along with burdens, a person is deprived of the right to the uniqueness and singularity of his own "I," subject to the will of a any tyrants, but he is happy with his captivity. The slave of motives, the obedient servant of conditions is saved from suffering, cheerful, joyful, full. He fears freedom and does not want it, dreaming that his benefactors will "wrap the shackles with soft cotton wool, so that pain will no longer be there; but the shackles will still remain shackles, and the human spirit will remain an eternal prisoner "[3]. Man is free only by that transcendental freedom, the possibility of which is ruled out by rationalism (V.F. Ern), any other liberation is illusory. The antinomy of the transcendental and empirical mind is insoluble in real life experience. It is eliminated in the existential experience of the individual, the overcoming of such antinomies is possible only as a personal act. But in the world of utopias there is no personality, its place is occupied by the psychological mechanism included in the system of universal necessity. 


\section{RUSSIAN UTOPIC THOUGHT}

Russian thinkers were among the first to doubt the ideal of well-fed equality, which lit up the European cities of the sun. In Russia, there are religious, "personalistic" utopias built on the principle of conciliarity, where a person, gaining a commonality, does not lose individuality and freedom, equality and happiness - the principles of an ideal society, is opposed by the personalistic Universum, where the love becomes to basic interindividual communication. Russian utopias, written in the spirit of Slavophilism: "Journey to the land of Orpheus" M.N. Shcherbatova, "City without a name" V.F. Odoevsky, "Life in a hundred years," G.P. Danilevsky, "Evening in 2217" by N.D. Fedorov refute the Western model. Russian utopia is not a constructed society, it's traditional dreams, (for example, the famous four dreams of Vera Pavlovna or the "Dream" of A.D. Ulybyshev), which further emphasizes the separation of the ideal from reality.

The danger of the proliferation of utopia was realized by many Russian philosophers. In the works of VS Solov'ev, FM Dostoyevsky, L.S. Frank sharply posed problems affecting the essence of human life, in an effort to acquire higher values, problems of happiness, beauty, freedom for all. They predicted the future history of mankind, depicts images where the insoluble historical contradictions of human nature converge, concerning food, freedom and faith. The idea that the perfection of life must be ensured by a certain social order or organizational structure, contains a contradiction. Cultivation of good and the eradication of evil are possible only as a result of self-improvement of a person, its spiritual upbringing. Coercion can not destroy evil. Utopianism, that includes good deeds through public order, has an immanent tendency toward despotism. The contradiction is created between the external order of life, represented by official values, and its internal arbitrariness, an accident. The dream of building the Tower of Babel "with their own hands" is carried out by suppressing real freedom, denying the spiritual foundations of human existence. The introduction of an installation for the forced transformation of life leads to results that are directly opposite to the goals set. Perfection is not only not achieved, but, on the contrary, evil and vices are flourishing. Good inevitably degenerates into evil - the creation of a new world is possible only by destroying the old, which has become an obstacle to the creative intent of man. The strength, resistance and stability of the old world for utopianism seem unnatural, irrational, - everyone should promote restructuring, providing a reasonable, well-fed life. But the benefactors of mankind quickly become its oppressors, destroyers, asserting by their actions what they wanted to rid humanity of - hatred and contempt for the individual. The stage of destruction is brought to its logical conclusion - the destruction of the foundations of life itself.

History knows quite a few examples of the real embodiment of the desires of the great Inquisitor - to correct the heroic deed of Christ, to take the sword to the aid of the cross, violence to help the free conviction and make all mankind happy. The desire to turn a utopia from an idea into a reality leads to the fact that everyday life becomes illusory, and the activity of the subject leads to results that were not assumed in the axiological choice. The world in the utopian values perspective is the object of activity A characteristic feature of utopia is the interpenetration of the imaginary and real, proper and essential, utopia is the satisfaction of the human need for the illusory mastering of the world around and a human itself.

Activity is directed not only at the struggle with nature and its rational alteration for the benefit of all people, but also for correction of the nature of a man himself. This view is inherent in Marxism, inheriting the traditions of classical utopianism. Moreover, the idea of a communist reconstruction of the world is a kind of result of a utopian tradition where Utopia acts as a program of social practice, the ideal of social development.

\section{Personality in Utopic Measurement}

The theory of creating a new "superman", which has deep roots in the history of both Western European and Russian utopia, was enthusiastically cultivated in the Soviet state, where man is regarded as a natural being, and the only goal of his existence is material power and material prosperity. A new, strong man-a man-god and a most basic equality-the equality of universal satiety (FM Dostoevsky) was to appear to the world.

Such social conception considers the "will to power" of a particular class as the universal nature of the individual. The individual becomes what it was formed, the objects of its outer world - imperatives that require passive obedience to them. Individual goals are completely subordinated to the public interest. The perfect man can and should want only what he receives and could not want what he do not receive. The basis of strengthening the socialist statehood in the minds of citizens are doublethink, lie, fear, the higher consolidating values are replaced by utopian goals. An ideology is created that must be accepted by a new person who was ordered to believe in impossible, to love what he hated before, to sacrifice his personal interests for the sake of abstract and great goals. Similar goals are forced industrial programs, the victory of the world proletariat, and communism. In fact, the personality disappears from the life of an integral collective as a transpersonal organism, society has an unconditional priority over its individual representative, who can be destroyed in the name of the public good, consisting in the movement towards universal harmony. Obviously, such an order leads to the elimination of man as a freely acting creative subject.

The way and form of communication between the acting individuals of utopia is determined by the goal of the transforming activity that is realized by the collective entity. Because of this, the highest value organizing the principle of activity is society, where selfishness is not overcome, but only its form changes. In the process of such activities, the individual does not overcome partiality, but, on the contrary, fixes it as a socially significant norm. The collective, thus, represents the community (integrity) of individuals (parts), united by formal, external values for them, which excludes the possibility of forming an integral harmonious personality.

In such a group, a person is deprived of the opportunity to be alone with himself. The more monolithic, effective in 
its achievements organization becomes, the more a person feel itself as integral part of it. There is no reason for fear of life where it is necessary to follow the "general will", where the one's own responsibility for personal existence is "absorbed" by a common responsibility. The society guarantees its readiness to ensure the safety of the individual. There is no place for creativity in utopian reality. A happy, problem-free hero of utopia is deprived of the need for selfexpression, self-improvement. Individual freedom is replaced by equality, the palliative of individual choice. The desire for it is treated as a riot, heresy, wine. (It is characteristic that in utopia there is no acting hero-loner, we always hear only the voice of the narrator).

The most important values and ideological orientations of the individual - time and death cease to exist as their own motives for inhabitants of the utopian world. "Everyone belongs to everyone" (O. Huxley), no one will ever come to grieve over the death of a single human being. Having lived with a young face and a slender figure, a Utopian dies same way he lived- carelessly. Neither he nor others around him do not willing and can not realize the terrible, significant, important because of the inevitable death reality: it simply ceases to exist for them [4]

The fundamental principles of classical rational utopia: belief in progress, the power of the human mind, the omnipotence of science, the possibility of achieving social justice as a result of historical development of society, the active nature of relation to global evolution are inherent in our times. However, modern historical practice has shown that the absolutization of science, the recognition of the scientific worldview as a universal foundation of culture leads to the rupture of deep, unformalized social relations, exacerbation of the alienation process, the consumer way of attitude to nature, to another person, leads to selfidentification losing. Ultimately, the total rationalization of social relations becomes a metaphysical justification for violence as a universal and most effective way of achieving socially significant, scientifically sound goals. Finding illusory freedom in the world created and investigated by person itself, does not save anyway from a rigid dependence on anonymous, alienated forces that suppress the personality.

\section{UTOPIA AS A MODEL OF SOCIO-CULTURAL FORECAST}

Utopianism in all historical versions, considers society as a mechanical system, suggesting that it is possible to establish the perfect social order by organizational measures, to achieve the desired goal. Even if freedom is the goal, then such organized production distorts its very essence, the unpredictable result is chaos, the arbitrariness of public life, carefully concealed by the external order, official values. Thus, the fundamental needs of man in freedom and creativity are distorted, fixed the partiality of the individual as its universal characteristic. The highest social value, the life goal of the individual is asserted consumption, alienation of a person appears as the norm of social life.

Over time, the classic utopia, narrating "about the best organization of the state" ceases to be a desired ideal. Increasingly, the foremost minds of their time speak of the fact that a prison, arranged according to all the requirements of hygiene, comfort, aesthetics, does not cease to be a prison. None of the utopias has indicated until now how to unite the individual with the collective without resorting to violence. Modern humanity craves more bread than freedom, but if it ever gets saturated in the future social order, it will wish to become independent.

Today, the motives for disappointment in the utopian ideal, about the future under the "iron heel" are sounding more and more often. In Russia and in the West, books are being written about the worst state - a peculiar society of Swift's struldbrugs, who "have no wishes in future." The scientistic classical utopia undergoes total transformation, developing into an anti-utopia in which the old ethical norms are seen as a symptom of a serious illness of a hypocritical society, rejecting the existence of a "right world" that requires observance of universally recognized and the only true norms and rules.

Most modern utopian projects are not models of a more perfect, rational world. These are rather alternatives to the present, or attempts to present realized consequences of certain theories and social technologies. The concept of perfection today has changed qualitatively. Traditionally, in the classical utopia the moral ideal is transcendental, primary, and the social organization is secondary, is the material for its realization. A detailed, consistent description of an imaginary, but localized in space - time society, built on the basis of an alternative socio-historical hypothesis, is constructed at the level of social institutions and human relationships. The world of utopias of our time (anti-utopias, dystopias, kakotopias, entopias) represents the monotony of the concretization of the classical ideal. This is either Orwell and Zamyatin's command system, with its inherent violence of enormous scale (spying, public executions of "dissidents", forcible brain surgery eradicating fantasy, etc.), or it is more gentle, based more on manipulation than on direct violence, the Western path called " Huxley's world".

This is a world where Shakespeare is forbidden, but food and clothing are abundant, where instead of truth and beauty they worship happiness and convenience. The happiness of the "numbers" without personality and imagination, the convenience of life of the "invisible bottle of reflexes", special for each caste - alpha, bet, scales. The world where the hand of the artist is "replaced by an exact machine", the poet - "the plant that generates happiness", and the man, on the orders of the Leader, is ready to embody any "great idea" without thinking about the consequences.

Anti-utopias of the twentieth century diagnose the "illness" of modern society, anticipating its possible future. Like the magnifying glass, they reflect the real world, become a protest against the technocracy, where once and for all established agreement of opinions are preserved by physical and spiritual violence, where the man is only the personification of a socially significant norm. Even the first novel by Wells "The Time Machine" (1895) carries features of an anti-utopia, which will then be indicated in the works of contemporary authors. The "Welcome Morlocks", where proletarians degenerating in a totalitarian society, are the 
direct predecessors of the workers who lead the "ant" existence in the novel "1984" by Orwell and the members of the lower castes in the novel" Brave New World" by Huxley. Conveyor production of socio-psychological stereotypes, habits, tastes, assessments, behaviors and perceptions destroys individual differences, stamping up people with identical faces, thoughts, souls. In the most rationalized society, a person is freed from the need to understand uneasy human relationships $\mathrm{He}$ seeks to possess the means for the sake of the means, blindly follow the leader and satisfied, being in a crowd of people with whom he is not bound by any feelings. The utopian social ideal of mass consciousness represents the value model of the average person, for whom beauty is substituted for profit, desire for truth is well-being, and happiness is bought at the cost of freedom.

Historical practice proves that utopias still satisfy the most important social need for social forecast, thus having a significant impact on the promotion of socially significant goals, values, and social ideals that can ever come true (C. Mannheim). The reformist aspirations of the Russian society of recent decades are largely oriented toward the mass utopian expectations of the people. Theorists and practitioners of political science, justifying a certain choice, represent it to the greatest extent appropriate to social ideals, national and universal values. Such projects, bypassing rational control, are assimilated by mass consciousness, become new utopias, organizing the aspirations of "too many" (F. Nietzsche), "a man-mass" (H. Ortega y Gasset). So, it is advisable to consider the pre-election political promises of registered parties for participation in the elections to the State Duma of the Russian Federation in December 2011, presenting the top of the 7 most impracticable [5]:

- "United Russia" calls one of the goals for the next five-year period - to enter the top five of the world's largest economies. Experts say that this is possible only "... if meteorites and atomic bombs fall on several countries of the world";

- Free housing - the poor promise the Communists. Families with low incomes will receive housing free of charge, and the rest will acquire it on credit at a rate of no more than $5 \%$ per annum and with a maturity of at least 10 years. Do not forget that the CPSU has already promised Soviet citizens the building communism by the 1980s. and the solution of housing problems by the beginning of the new century. In fact, we have more than $40 \%$ - families with low incomes. There are no building capacities in the country to implement such a construction. According to economic laws, lower interest rates will be accompanied by higher prices for apartments;

- "Patriots of Russia", whose ideology, according to the program, is based on patriotism, offers a national idea in the spirit of the classical utopia - creating in the country a society of equal opportunities - with political stability, social justice and sustainable economic development - "justice for all, happiness for everyone "by transferring illegally privatized property to its rightful owners - the people and the state. The implementation of this slogan requires a change in the Constitution of the Russian Federation and the state itself, which conducted the privatization of the 1990s. which inevitably leads to general chaos.

- "Righteous Deed" promises Russia's accession to the European Union. Accession to the EU is not a matter of today, but a task for the future. "We are united by the proximity of cultures and the common history. The main thing now is to determine the vector of our movement, "the" right-wingers "believe. The question, at least, is controversial.

- "Higher education for all and for free " promised to the Russians the leader of the LDPR V.V. Zhirinovsky. To abolish the State Unify Testing and accept all those who wish to enter higher education institutions, and, at the end of the first session, leave in the institutions those who able and wish to continue their studies. The implementation of this idea threatens to increase corruption in education and paralyze the work of universities;

- «Free accommodation for the third child." Russian Social Democrats from" Fair Russia" combined "right" and "left" slogans, creating an utopian program "for all" - building a new socialism of the 21 st century that unites socialist and democratic ideas - allocating state interest-free loans to young families to purchase an apartment or at home. At the birth of the first child $25 \%$ of the loan will be repaid off, the second child birth let repay off half credit, and for the appearance of the third child in the family, the state will fully repay the loan. Experts argue that the implementation of this program will require redistribution of budgetary funds, and good intentions can turn into significant problems in the social security system

- Land tenure - for middle class. The program initiative of "Yabloko" assumes the embodiment of the traditional dream of the Russian people - land parts purchasing The party promises to give out 30 acres of land in the European part or 60 - beyond the Urals for individual construction. According to G. Yavlinsky, over the next 7 years, not less than 14 trillion rubles can be mobilized for implementation of the program. That will allow to build 12-15 million private houses with an area of 130-150 square meters, include roads and infrastructure. But there is only condition - it will be a limited period that is allocated for the construction of the house, 3 years. If during this time the house is not built - the land is transferred to another person. That means this pre-election promise is designed exclusively for middle class, which does not constitute a majority in Russia. Its implementation will inevitably lead to an increase in social tension.

Many electoral programs of any level of power are similar, they have no concrete promises on specific areas of 
activity, it is just saturated with difficult terminology and populist slogans. There are usually not contains any dates or specifies for fulfilling promises like these. However, according to VTsIOM on May 14, 2012, a record number of Russians (82\%) feel happy [6].

\section{CONCLUSION}

Utopian thinking is afraid of real freedom, hopes for a miracle and awaits authoritarian decisions. The system of socialist ideas of R. Owen, the Garden of Epicurus, Harmonihall, the communes of young Catholics E. Mounier, and many other attempts to create a local experiment for the embodiment of ideas into reality failed. The task of modern reformers developing projects for a new better future is to destroy utopian myths, but not to create new ones?

\section{REFERENCES}

[1] Sventohovsky A. The history of utopia. Moscow: Librocom, 2014, $454 \mathrm{C}$.

[2] Myth, strength and violence in the philosophy of J. Sorel // https://www.runivers.ru/philosophy/logosphere/471679/ (circulation date June 11, 2018)

[3] Frank SL. The Heresy of Utopianism // http://www.odinblago.ru/eres_utopizma (date of circulation June 10, 2018)

[4] Huxley O. Brave new world. M.: AST, Neoclassic, 2017. 352 p.

[5] Khalutornykh ON Utopia as a social technology or life in the system // Materials of the XI International Conference "Public Administration: The Russian Federation in the Modern World". Moscow, FGU MSU, May 30 - June 1, 2013 Moscow, 2013 Part 3. Pp. 742-746

[6] VTsIOM on May 14, 2012 A record number of Russians feel happy // https://www.rbc.ru/society/14/05/2012/5703f7759a7947ac81a67ea0 (circulation date June 10, 2018). 